\title{
(Post)-Methodism: Possibility of the Impossible?
}

\author{
Seyyed Mohammad Reza Hashemi \\ Tarbiat Moallem University, Tehran, Iran \& Iran Language Institute, Iran \\ Email: hashemi_ili@yahoo.com
}

\begin{abstract}
This paper is a critical review of the concept of post-method language teaching. The author first presents a quick review of the history and concept of method and introduces the concept of postmodernism as a source of influence for post-method-ism. The author, then, adopts a critical approach to reviewing the concept of post-method and the idea of searching for "an alternative" to method (Kumaravadivelu, B. (1994). The postmethod condition: (e) merging strategies for second/foreign language teaching. TESOL Quarterly, 28, 27-48.). The paper argues that these two concepts can have the same mode of existence in reality and the difference between them is only a virtual one that would exist in the mind of the practitioner/expert. Finally, it is further argued that skepticism toward the concept of method and the search for "an alternative" to method (as Kumaravadivelu has put it) would not guarantee the future of practice in the field of language teaching, as this search has not proved to bridge the gap between theory and practice.
\end{abstract}

Index Terms - method, postmethod, postmethodism, theory, practice

\section{INTRODUCTION}

As a broad and burgeoning field, language teaching has witnessed accumulation of knowledge and diversity of practice from the early years to the present time. Perhaps, theories of language teaching came to life as early as the first teacher started thinking about the career; and this would probably go back to centuries ago if we could accept that "language teachers have been with us as long as there have been languages" (Savignon, 2007, p. 207). However, language teachers' knowledge, in the course of time, has assumed different shapes based on their experience, intuition, deductive reasoning, inductive experimenting and also their individual and social understanding.

Having enjoyed abundance of research in various areas, soon the field of language teaching was replete with theories that would inform practice. Theory production in language teaching, however, seems to have followed the tradition in disciplines such as education, psychology, sociology, linguistics (see Savignon, 1991, 2007). Although the recorded history takes language teaching seriously from the Middle Ages (Howatt, 2004), state-of-the-art theory production appears to have gained importance since the 40s and 50s, portraying language teaching scholars' ambition to keep the field competitive with other disciplines and to forge a scientific identity for it. This was probably due to the "tendency of social sciences to model themselves after the physical sciences through use of empirical-analytic approach" (Pennycook, 1989, p. 594). Whatever the reason, the movements led to proliferation of theories and models, thus affecting the course of practice through realization of methods and procedures. With this drive for change, then, came turning points in the history of language teaching.

On the whole, according to the observations and reports by scholars in the field (e.g. Anthony, 1963; Howatt, 1984; Kelly, 1969; Kumaravadivelu, 1994; Richards and Rogers, 2001; Swaffar, Arens, \& Morgan, 1982), it is possible to draw a distinction between three periods in the history of language teaching: the gray period, the black-and-white period, and the colored period. (Using colors in naming the periods would allow of understanding them as sharing the same nature, as if the difference would be a result of the light in which one views them or the context in which they are viewed!)

The gray period in the history of language teaching can be understood as the pre-method era. Pre-method here would by no means imply absence of methods. As the color gray suggests, in the pre-method era, methods do not appear as categorical, systematic entities; rather, they are mixed and barely distinguishable. This is a period of time between the 14th and the late 19th centuries (see Howatt, 2004). The practitioners in the gray period would follow their intuition, common sense and experience in the course of teaching. So the art of teaching for them was very personal. Nevertheless, contributions made by the gray-period practitioners proved to be really valuable as in their custody the field of language teaching in its embryonic form continued to survive. The contributions made by the 16th-century masters of language teaching (e.g. Bellot, Florio, Holyband: see Howatt, 2004) is a good example. Then, with the spread of English in the 17 th and 18th centuries, many teaching hours were devoted to the pursuit of effective techniques and procedures for teaching the language. And by the end of the 19th century the quest for method(s) had already begun. At this point, comes the black-and-white period (the era of methods: between the late 19th century and the late 20th century) in language teaching-more specifically in ELT.

In the black-and-white period, choices made by teachers in the process of teaching are of either-or nature-good vs. bad; however, the search for better methods follows a scientifically sound philosophy. Moving beyond GTM, then, ALM becomes the leading pioneer of a generation of principled practice, later referred to as "designer" or "brand name" 
methods (Richards \& Rogers, 2001). In itself, the era is colorful, but the practitioners' perspectives are black-and-white when it comes to inventing a method and applying it in practice. On the one hand, there are language-centered, structure-based methods (ALM, SLT, TPR); on the other hand, pendulum swings toward learner-centered, learning-oriented methods (CLL, Suggestopedia, Silent Way, Whole Language). With the emergence of CLT and post-CLT approaches (e.g. CBI and TBLT), however, the field enters the colored period.

In the colored period of language teaching, teachers are no more colorblind! They are, hopefully speaking, reflective, dynamic and autonomous. Being as creative as a painter, the teacher in this era can see, distinguish between, and understand the colors, knowing how and where to use how much of what to create perfect harmony!

As mentioned above, the movement (change of perspective) from the gray period to the colored period of language teaching is profoundly influenced by theory and research in the field and the changes in other disciplines. In linguistics, for instance, change is attributed to Firthian linguistics, Chomsky's generative-transformational linguistics (1975), Halliday's systemic-functional linguistics (1985), developments in discourse analysis and pragmatics (e.g. Bakhtin, 1986; Blum-Kulka, House, \& Kasper,1989; Brown \& Yule, 1983; Gumperz, 1982; Sinclair \& Coulthard,1975), new agenda in critical discourse analysis (Bourdieu, 1991; Fairclough, 1989; Wodak, 1989), and the genre movement (Swales, 1990; Bhatia, 1993).

Another discipline that helped ELT find its way was psychology: Skinners behaviorism (Skinner, 1957), Chomsky's immediate reaction (1959), Piaget's developmental and cognitive psychology $(1951,1971)$, Vygotsky's work on social constructivism and his notion of ZPD (1978, 1986), Roger's client-oriented psychology (see Roger, 1968), Maslow's humanistic psychology (1967), the light shed by Gestalt psychology, etc.

As powerful sources of inspiration, philosophy and education also contributed a great deal to the development of thought in language teaching, in the course of theory making and critical analysis of practice. The liberal "Socratic" method, and Plato's functionalist model of education along with Aristotle's notion of moral education are early reflections which have directly influenced the practice of teaching for many years. Among modern philosophers and educationalists, the works of John Dewey addressing his progressive view of education and emphasis on reflective teaching and learning are worth being mentioned. Another educational philosopher, Paulo Freire had a great role in development of critical thought and practice (Freire, 1972, 1998). Thoughts from sociology have also had great impact on the nature of theory production in language teaching. Giroux's concern for linking schooling to democratic principles of society (Giroux, 1988), Gramsci's (1971) notion of "hegemony" which has crept into critical discourse analysis, and Foucault's study of shifting patterns of power (1972, 1980) are instances of such influences on education, and subsequently, on language teaching. Darder, Baltodano and Torres (2003) argue that the Frankfurt school with members like Horkeimer, Adorno, Benjamin, Marcuse, and Habermas had great influence on critical educational thought, challenging the "traditional forms of rationality that defined the concept of meaning and knowledge" (Darder, et al., 2003, p. 8).

The above mentioned factors and forces, along with many others, caused the field of language teaching to gather momentum as it moved toward reflective thinking and practice. And methodizing, although not positively acknowledged, can be considered to be the earliest attempt at bringing about change. The following section is devoted to the concept of methodism and its status in the field of language teaching.

\section{ON METHODIZING}

Oxford Dictionary of Word Histories (2002) describes the origin of the word "method":

"Originally a method referred to a 'prescribed medical treatment for a disease'. The word came via Latin from Greek methodos 'pursuit of knowledge', based on hodos 'way'" (emphases in original).

As its origin suggests, the concept of method reminds us of prescription and imposition. It is linked with tradition when it is perceived as "way." Also, concentrated within method is the concept of power which attracts considerable weight to the concept, especially when connected to religion and tradition. So the concept of method is deeply rooted in history and culture and would imply different meanings for different people.

In education, perhaps, method came into being with the teaching of the first teachers (for example religious leaders, philosophers, artists). Method, in its contemporary sense, however, is said to be first used by Petrus Ramus to refer to teaching a curriculum (Doll, 2001). Doll also pointed out that the strong version definition of method would link it to scientific manner. This view was later balanced by Dewey.

With his liberating point of view, John Dewey adopts a critical approach to establishing a kind of "pragmatic naturalism" (Noddings, 1998, p.25). For Dewey, emphasis should be placed on the learner experiences, joining together action with reflection, and showing respect for learners' choice (Dewey, 1916/1966, 1938/1963). This is in fact humanizing education, softening the rigidly conceived concept of method.

In language teaching, Jan Amos Comenius is among one of the first to introduce method and methodic order in the strictest sense. As Howatt (2004) describes, Comenius takes aim at theorizing a universal system of education through religious and tradition-based framework: "The Comenian curriculum is founded on the concept of natural order as the true reflection of divine order, a seventh-century concept which finds an echo in all contemporary science from Kepler to Newton" (Howatt, 2004, p. 47). Curriculum in the Comenian sense, then, is the embodiment of method to be observed by the practitioner, a devout follower who progresses toward the last stages of perfection. The moves are 
prescribed and inevitable.

Introducing the concept of method in its modern sense, then, came a series of proposals made by scholars who are now known as the originators of the methods (Asher, 1969; Curran, 1972, 1976; Hornby, 1954, 1959; Krashen \& Terril, 1983, Lozanov, 1978, etc.). In essence, method in this era becomes a meaningful concept with a top-down, authoritative nature. Assigned to the concept then are definitions and models, thus making method the core of teaching.

For Anthony (1963) method contributes to systematic teaching of the materials. Based on Anthony's (1963) view-representing method as the link between theory and practice-Richards and Rodgers $(1986,2001)$ proposed their own model. In this model, the concept of method is geared to three levels of conceptualization: "a method is theoretically related to an approach, is organizationally determined by a design, and is practically realized in procedure" (Richards and Rodgers, 2001, p. 20). Method, from this perspective, can be understood as the heart of the pedagogy. Method, in this sense, although creating a pedagogical hierarchy, reveals a fluid nature at different levels of perception. At the level of theory, method is defined within a certain belief system; yet, the same concept can be realized differently by the lower level practitioner at the level of practice. The concept, defined in this way, appears to have two modes of existence, one in the mind of the theorist, the other in the hands of the practitioner.

But it was in the late 80s and early 90s that the concept of method attracted strong criticisms (Allwright, 1991 cited in Kumaravadivelu, 2006b; Kumaravadivelu, 1994; Pennycook, 1989; Prabhu, 1990). Among others, Kumaravadivelu seems to be the severest critic of the concept of method.

In the following sections, with a glance at the movement toward de-methodizing, Kumaravadivelu's notion of postmethod will be critically reviewed.

\section{TOWARD DE-METHODIZING IN ELT}

Probably the first dissenting voices expressing disenchantment with the concept of method in language teaching were those of Mackey (1965) and Finocchiaro (1971). Mackey (1965) criticized the vagueness and inadequacy of method, asserting that by sticking to only one aspect of the subject methods limit themselves. In a beautifully written paper, Mary Finocchiaro criticized the one-dimensional, method-oriented practices of the time:

Dogmatic statements related to methods and techniques have troubled interested, conscientious teachers who are aware (1) that an either/or answer to any facet of educational theory or practice limits both teacher and learner creativity, and (2) that an eclectic integrated approach....(Finocchiaro, 1971, p.3)

In the early 70s, Finocchiaro invites teachers to develop creativity in teaching and not give into mesmeric quality of only one theory or method. It is until the early 80 s when language teaching scholars start giving the issue more serious thoughts.

Following Mackey (1965), Stern (1983) put forward the notion of "the break with the method concept" (Stern, 1983, chap.21), stressing that "language teaching is now no longer conceptualized in terms of single undifferentiated methodological prescription" (p.494). Stern (1983) did not reject the concept of method; rather, he expressed concern about blindly following imposed methodologies.

A very serious criticism of the concept of method, however, is reflected in Pennycook's 1989 article. Voicing deep skepticism about the concept, Pennycook (1989, p. 590) argued that method "is articulated in the interests of unequal power relationship." He even took a step further by asserting that "all education is political and all knowledge is 'interested"' (Pennycook, 1989, p. 590). Although this view seems rather extreme (as even if "all knowledge is interested," it will not necessarily indicate that all the recipients of it are interested to the same degree-if it were so, theory construction could not have a future), it rightly implies that concepts such as knowledge, theory, method carry, within themselves, an august quality of dictating and imposing nature:

The method construct...not only fails to account adequately for the historical conditions, but also is conceptually inconsistent... It is also questionable whether so-called methods ever reflected what was actually going on in the classroom. (Pennycook, 1989, p. 608)

Also, works by Clarke (1990), Clarke and Silberstein (1988), Prabhu (1990), and Richards (1990), cast critical reflections on the nature of method-oriented pedagogy in the field. Prabhu (1990), for instance, argued that the search for the best method would be futile. To Prabhu, every method has some value; nonetheless, Prabhu (1990) pointed out that teachers' subjective understanding (their "sense of plausibility") is much more valuable than blind blending of the methods or haphazard eclecticism.

Brown (1991) attributed the development in the history of language teaching to what he would call "collective wisdom" of the previous years. In light of freethinking, "collective wisdom" would not only refer to the knowledge possessed by experts and theorists, it would also be a result of contributions made by teachers and practitioners at the bottom of the hierarchy.

Finally, it was the first issue of 1994 TESOL Quarterly which made announcements of the advent of a new era! The first article in this issue harshly criticized the hierarchical nature of theory-practice relationship. In this article, Clarke called for a "complete re-orientation of the profession" through turning "the hierarchy on its head, putting teachers on the top and arraying others ... below them" (Clarke, 1994, p.18). The second article in the same issue, then, paralleled Clarke's line of argument but dug deeper into the problem of method-oriented practice, introducing the field to the concept of "postmethod condition" (Kumaravadivelu, 1994). This view was later shared by other scholars: those who 
tended to sing a "requiem for methods" (Brown, 2002) and those who referred to the past history of methods as an "embarrassment" (Richards, 2001).

Before reviewing post-method-ism in language teaching, an overview of the concept of postmodernism seems inevitable.

\section{Postmodernism at a GlanCE}

As acknowledged by Kumaravadivelu (2006a) the source of inspiration for philosophizing "postmethod" is postmodernism. So before dealing with the postmethod pedagogy, it would be helpful to take a glance at the concept of "postmodernism."

Actually, it is hardly possible to present a definition of the concept of postmodernism ("possible" in the sense that a definition needs to enjoy objective quality based on the consensus of expert opinion), as it is not compatible with-and sometimes it is even skeptical toward - the concept of definition itself (see H. W. Janson \& A. F. Janson, 1995). "Post-" according to H. W. Janson and A. F. Janson (1995) implies a state of change. So postmodern would suggest moving away from or beyond the current modern condition, putting the world in a state of change. The term was first used in the late 40 s to refer to the final stage of civilization that had begun with Renaissance (H. W. Janson \& A. F. Janson, 1995). As a radical movement, however, postmodernism, with an anti-functionalist nature, was first used in architecture by Ventury and his wife who critically reacted to the modernist principle prescribing that form should follow function (Hutcheon, 1989; H. W. Janson \& A. F. Janson, 1995). Postmodernism then emerged in painting (e.g. works of Penck, Salle, Tansey) and in photography (e.g. works of Kroger, Lemieux, Sherman). In the works of art by such postmodernists some features are easy to spot: reordering of the orderly, reshuffling and de-juxtaposing of the unchangeable; presenting and re-presenting the un-presentable, and rule breaking (see Hutcheon, 1989; H. W. Janson \& A. F. Janson, 1995). The same features are easily observed in postmodern cinematography, seeking to trespass borders of logic and reason, mixing reality and fantasy, creating a new visual culture, etc. (e.g. movies directed by Lynch and Tarantino).

In philosophy, the works of Derrida and Lyotard contribute to the understanding of the postmodern. Derrida draws attention to the "imperialism of theoria" (1978, p.85). His proposal reveals a unique decentering quality called "deconstruction":

as Derrida has pointed out, parenthetically... :

... (but deconstruction is not a critical operation; it takes critique as its object; deconstruction at one moment or another, always aims at the trust confided in the critical, critico-theoretical agency, that is the deciding agency, the ultimate possibility of the decidable; deconstruction is a deconstruction of critical dogmatics). (cited in Wolfreys, 1998, p. 58)

From a Derridean perspective, one can challenge the idea of method, pattern, framework, theory, etc., considering the "other possibility" and "possibility of the other" as "there is always already the trace, the mark, the trait, différance within the structure, within identity, which disables mastery ahead of the encounter or even with subject of inquiry" (Wolfreys, 1998, p. 191: emphasis in original). From this point of view, a priori omniscient perspective is no more the only source for perception; rather, perceptions of the same entity would prove to be of different value from encounter to encounter, from person to person, from mood to mood, etc.

Another influential postmodern thinker is Lyotard. Lyotard describes postmodernism as "an incredulity toward metanarratives" (1984, p. xxiv). Lyotard's skepticism toward metanarratives, his disbelief in Grand theories, and doubts he casts on the status of knowledge in era of post-structuralism and post-industrialism seem to act as the essence of his postmodern thinking. Interestingly, Lyotard does not conceive postmodernism as being the end of modernism: "A work can be modern only if it is first postmodern. Postmodernism thus understood is not modernism at its end but in the nascent state, and this state is constant" (Lyotard, 1984, p. 79). So there should not exist one form of postmodernism with one single definition. According to Jameson 1984, there are different types of postmodernism: baroque postmodernism, rococo postmodernism, neo-classical postmodernism, etc.

On education, too, postmodernism had an impact as "postmodernists attacked notions of reason, means-end thinking, theory teaching;" and this consequently caused "a major shift in our conception of inquiry" (Beck, 1993, p. 5). Questioning the practice of problem posing in schools, Beck (1993) suggested that education should help students develop cultural-political understanding through "democratic and dialogical emphasis of postmodernism, its questioning of the motives of authorities and its downplaying of the role of experts" (Beck, 1993, p. 8). However, Beck (1993) called for a kind of balance by cautioning that "we should not dismantle all structure and hope that something happens" (p. 9). Although strong version postmodernism would not let in a prudence of this kind, Beck does have a point here.

In language teaching, however, postmodernism made its presence felt, wearing the disguise of postmethodism.

\section{A CRITIQUE OF THE POSTMETHOD CONDITION}

Although the field had started to experience the postmethod condition in the late 80s, it was Kumaravadivelu (1994) who has officially introduced the term. Kumaravadivelu (1994) based his argument on a number of possibilities signified by the postmethod condition. The first possibility is the "search for an alternative to method rather than an 
alternative method" (1994, p. 29). Secondly, he proposed that teachers should be empowered to "theorize from their practice and practice what they have theorized," this he calls "teacher autonomy" (p. 30). Finally, he puts forward the concept of "principled pragmatism" which is the result of "informed teaching and critical appraisal" (p. 31). Based on his previous work in the context of CLT (Kumaravadivelu, 1992, 1993), he, then, presents a set of macro-strategies to help teachers discover their own context-sensitive micro-strategies (1994, 2001, 2003, 2006a). Also, Kumaravadivelu (2001, 2003, 2006a) conceptualizes three parameters for postmethod pedagogy. The parameter of "particularity" that-from Elliott's (1993) "hermeneutic principle of situational understanding" (Kumaravadivelu, 2001, p. 538) - highlights the context-sensitive nature of language teaching. The parameter of "practicality" which, building on the third possibility mentioned above, aims at connecting theory and practice to "rupture the reified role relationship between theorizers and practitioners" (Kumaravadivelu, 2006b, p. 62). And the parameter of "possibility" which seeks to spell out the "importance of acknowledging and highlighting students' and teachers' individual identity" (Kumaravadivelu, 2006a, p. 174). Kumaravadivelu's model looks promising. However, a couple of critical reflections and reactions are in order!

Liu (1995, p. 175), for instance, reacts to the notions of "futility/demise of the search for better method" and emphasis on finding "an alternative to method." Liu (1995) is correct in that postmethod cannot be considered as an alternative to methods because at the level of practice they both require realizable procedures. So postmethod without method is theory without practice or an alternative to thinking but not an alternative form of doing, and this would undermine the parameter of "practicality." Further, Liu (1995) believes that the term "principle" is more accurate than "macro-strategy" and argues that "macro-strategies should not and cannot replace methods" (p. 175). Liu (1995) also contends that classroom objectives are accomplished through use of methods.

In response to Liu (1995), Kumaravadivelu (1995) points out that by method he means what is "conceptualized by theorists" not what is "actualized by practitioners" (p. 177). He also notes that he is not alone in making a claim about the "demise of method" by making reference to Bartolomé (1994). Kumaravadivelu (1995) continues by emphasizing the theory neutral nature of his framework and insists that his model is an alternative to methods.

However, what is subjected to criticism by Kumaravadivelu is not method in the sense defined by the previous scholars (e.g. Anthony, 1963; Richards \& Rodgers, 1986). By offering a personalized definition of method, Kumaravadivelu $(1994,2006$ a) actually creates the concept he wishes to criticize, in a way that the concept would more comfortably lend itself to criticism. Kumaravadivelu (2006a) draws a distinction between "method" and "methodology," introducing the former as a "construct" and the latter as a "conduct" (Kumaravadivelu, 2006a, p. 162). He asserts that method "is an expert's notion" (2006a, p. 162) based on theories, whereas methodology, by contrast, "is what the teacher does in the classroom" (2006a, p. 163). In light of the traditional definition for method, however, it would be hardly possible to sharply distinguish between "method" and "methodology" only because they are realized differently in two different discourses. Kumaravadivelu's definition limits the concept of method to only what goes on in the mind of the expert. However, it would be possible to even create a postmethod definition for the term method: method as conceptualized and actualized by practitioners. This confirms the inevitable existence of method even in the postmethod era. As a matter of fact, these two concepts are inextricably interwoven and mutually dependent. So the quest for an alternative to method would be meaningless; instead, our search is for an alternative perspective for renewing our understanding. This view would in fact encourage us to accept and acknowledge the subjective and compatible being of method, while rejecting its "interested" (to borrow form Pennycook, 1989) objective, and manipulative existence. Method in this sense is not dead but multiplied!

Kumaravadivelu (1995) refers to Bartolomé (1994) to stress that he is not alone in imagining a scenario for the death of the method. However, in "Beyond the Method Fetish," Bartolomé (2003) does not put the blame on the concept of the method but on the "fetish" resulted by ignorant use of method (see Bartolomé, 2003). Actually, she asserts that there is "a disarticulation between the embraced method and the socio-cultural reality with which each method is implemented" (Bartolomé, 2003, p. 410). Hence, for her it is the "myopic focus on methodology" (ibid) which is worthy of blame. She even speaks of "effective methods" in a given "socio-cultural context" (2003, p. 411). For Bartolomé, method is not dead:

the informed way in which a teacher implements a method can serve to offset potentially unequal relations and discriminating structures and practices in the classroom and, in doing so, improve the quality of the instructional process for both student and teacher. (2003, p. 412)

Another claim made by Kumaravadivelu $(1995,2006 a)$ is that his macro-strategic framework is "theory neutral." But the question inspired by Pennycook (1989) asks whether any framework or theory can be theory neutral. It should be noted that Kumaravadivelu builds his macro-strategic framework by making reference to the literature on language teaching that is by no means theory free. Even without any supporting literature, one could not neglect the fact that any discourse, educated or uneducated - in this case highly educated, cannot be free of orientation, culture, attitude and thinking.

Postmethod pedagogy for some is not but the same as CLT movement (Bygate, Skehan, and Swain, 2001). Bygate et al. argue that "communicative language teaching was explicitly a post-method approach to language teaching (see notably Brumfit and Johnson, 1979; and Brumfit, 1988) in which principles underlying the use of different classroom procedures were of paramount importance, rather than a package of teaching materials" (Bygate et al., 2001, p. 2). 
Developing similar arguments, Bell (2003) points out that "many of Kumaravadivelu's strategies - negotiated interaction, integrated language skills, learner autonomy, and so on-look remarkably like CLT" (p. 332). Focusing on the relationship between method and postmethod, Bell (2003) reminds us of the constraints the postmethod condition has brought with it, threatening teacher's "sense of plausibility" by "deconstructing methods" (p.333). Kumaravadivelu's reaction to Bell's comment, then, pushes the argument to the other extreme: "postmethod pedagogy on the contrary can be considered to put a premium on the teacher's sense of plausibility" (Kumaravadivelu, 2006b, p. 73). Apparently, both extremes are possible! Postmethod realized as a liberating discourse can indeed nurture subjective understanding of the practitioners and free them from deeply rooted dependence on prescriptive, prefabricated patterns of practice. At the same time, if interpreted in its utopian sense, it may corner the less experienced practitioner by forcing him/her into an isolated frame of mind and create an unbridgeable gap between the teacher's fantasy and the reality of the moment. Bell (2003), however, prefers to connect the two controversial concepts, arguing that "method and postmethod can also be seen as inevitable and necessary dialectical forces: the one imposing methodological coherence, the other deconstructing the totalizing tendency of method from the perspective of local exigencies" (Bell, 2003, p. 334). Bell's point sounds sensible! However, he does not clarify the practical aspect of his proposal. Bell (2003) does not make clear what he means by "deconstruction of method." Is it deconstruction in the Derridean sense? Again an appealing theory breeds vague realization of its practical value!

Having devoted many years to examining theory and practice in the field of language teaching, Larsen-Freeman (2005a) surprises the proponents of postmethod pedagogy by asserting: "I certainly do not want to throw out the concept of method" (p. 22). And to help teachers avoids using methods inappropriately," Larsen-Freeman (2005b, p.5) presents her seven "i's": "moving form ideology to inquiry while challenging notions of inclusive generalizations, imposition leading to implementation, intactness, and immutability." She judiciously states that "methods are not immutable in practice. As teachers gain experience, they come to understand a particular method differently (Larsen-Freeman, 2005b, p.11).

More recently, in a paper examining teacher beliefs about the claim that methods are dead, Bell (2007) reports that in the minds of teachers methods are not dead. Bell (2007) explains that teachers show awareness of how useful methods are. He concludes that "postmethod need not imply the end of the methods but rather an understanding of the limitations of the notion of method..." (Bell, 2007, p. 143).

From the above mentioned arguments, it should now be clear that some scholars are not willing to forget about the concept of method and that the concept of postmethod exists with a paradoxical nature. Out next concern, thus, would be to investigate the paradoxes.

\section{PARTICULARITY-POSSIBILITY VS. PRACTICALITY}

As reviewed above, the parameter of "particularity" contributes to the context-sensitive aspect of the pedagogy; the parameter of "possibility" takes into account students and teachers' individuality; and the parameter of "practicality" establishes a direct link between theory and practice, questioning the status of expert knowledge (Kumaravadivelu, 2003, 2006a). The three parameters thus are expected to work in harmony to turn the "pedagogic wheel" (Kumaravadivelu, 2003). However, there are times when forces of particularity and possibility are applied in the direction opposite to that in which practicality is exerting pressure. This would be proof of existence of paradoxical forces within postmethod pedagogy. More specifically, postmethod practicality parameter allows the teacher decenter the source of power (e.g. expert opinion) and produce the theory as if he/she were the center. Parameters of particularity and possibility are then responsible for context-sensitive elements and individuality of the people involved. Appealing! Too idealistic, though! Let us now deconstruct the idealistic make-up of the theory which is shaped in a universally acceptable vacuum. In doing so, we need to take a highly center-oriented culture as an example-e.g. a context like Iran.In Iran, the religious culture of people guides them to appreciate and worship only one source of power, Allah. This deeply rooted religious belief, directly or indirectly, influences every aspect of the people's life, leading them to seek unification everywhere. Iranian traditional music, for example, is homophonic. In most cases, it is characterized by a single melodic line which moves around a theme with repetitions. Iranian works of calligraphy and more recently typography also show tendency toward the center-forms converge toward the center and in many instances unification is observed. Iranian discourse is also circular with a lot of shifting and a lot of moving around the main theme. This can be easily observed in the works of Rumi, for example. Iranian painting, although believed by some as not being center-oriented, does reveal great tendency toward unification of form (e.g. schools of Harat and Tabriz). In Iranian mysticism, we have the concept of pir (an old person with divine qualities, close to master in the traditional sense) who is the source of inspiration for his younger disciples in their quest for truth and divinity. In its educational sense, the concept is so close in meaning to the concept of teacher. In class, thus, it is the teacher who is at the center of attention and even the seating arrangement of the students would show the superiority of the teacher as the source of knowledge and discipline. Teachers then are expected to follow the predefined educational policies. The hierarchy, therefore, imposes itself upon the curriculum and education in such a context would certainly incline toward the legitimacy of a top-down pedagogy. Authority or expert knowledge in this context is hardly ever questioned and almost never decentralized, as it would be considered against the norm. Now the question is: "How is it possible to adopt a postmethod attitude and forget about the expert knowledge as the center in a context where people highly admire 
capital-T Truth, the Truth which is never pluralized? So postmethod pedagogy, that might be considered by some as the movement toward humanizing the practice in the curriculum, would in such a context, lead to dehumanization of the target group by isolating them from their history and culture.

This paradoxical nature of the postmethod pedagogy, in fact, would negatively affect the teachers in this context, especially the traditional ones. A postmethod teacher is very different from a traditionally trained teacher. A postmethod teacher can sometimes be compared to Orson Welles' Don Quixote-for some crazy enough, for others too crazy. Such teachers would undergo lots of pressure if not appreciated by the peers, students, employers, etc.

\section{MACRO-STRATEGIC FRAMEWORK}

Kumaravadivelu (1994, 2003, 2006a) offers macro-strategies and reminds us of the existence of micro-strategies. He also uses possessive pronoun MY to refer to the macro-strategic framework (2006a, p. 199). As Bell (2003) asserts, among these macro-strategies one can hardly find a maxim that is totally novel by nature. These are, in fact, the beautiful commandments that have continued to live for years in the field. The point, however, is that presenting a framework of any kind, is completely against the liberating nature of a movement that would put aside prescription. Presenting macro-strategies would be of prescriptive nature. Macro-strategies are very similar to Grand narratives and they are not welcomed by a movement like postmodernism. Although Kumaravadivelu encourages teachers to discover their own context-sensitive micro-strategies, he is consciously or unconsciously, inducing the audience to accept his macro-strategies as a point of departure. This is re-creating the hierarchy in a new discourse system. At the top, there is Kumaravadivelu's persuasive theory published in professional and well-known journals or by powerful publication houses; at the bottom, on the other hand, there are teachers and teacher candidates usually so impressed by the theory that would not think of any type of extending or personalizing.

\section{CONCLUDING REMARKS}

Derrida once wrote "philosophy died yesterday...thought still has a future" (1978, p. 79). If one could say "method died yesterday," my immediate reaction would be: "but practice still has a future." Paradoxically, method will live as long as practice will. How could any practice be method-free? Method is a strange concept, old and new, meaningless and meaningful. With all systematicity it bears and the order it creates, method swings back and forth from meaninglessness to meaningfulness. At times, it deals with and leads to well-defined patterns as realizations of coherent thoughts and informed practice. There are also times when method equals chaos, especially when in the hands of unimaginative users, unreasonably insisting on sticking to their dogmatic principles. Methodic patterns as they emerge, though, are the quintessence of excellent harmony. However, when dictated and followed blindly, patterns would lose their context-sensitive meaning. Prescription of contextually isolated patterns would, then, impose limitation and this limitation will result in fossilization of practice. Teachers with dynamic minds would never let that happen, struggling to create coherence and meaning as they discover, perceive, interpret, implement and modify methods. In this sense, method and postmethod are exactly the same-difference between method and postmethod would not, thus, exist in reality.

More specifically, post-methodism, like postmodernism (see Marshal \& Peters, 1999: in Keeves \& Lakomsky, 1999), would allow radical breaks! At the same time it is believed to stay in dialectical relationship with Methodism (Bell, 2003). Method and postmethod are, then, both possible (in dialectical relationship) and impossible (radical break), thus reminding one of "hermeneutics of suspicion" (see Solomon \& Higgins, 1996, p. 300), emphasizing philosophies over one Philosophy (Solomon \& Higgins, 1996), accepting discourses over one discourse.

So from different perspectives, (post)-method reveals different qualities, different modes of being. One may move beyond methods, but the concept of method will never die, just like Christmas thanksgiving, the way of Samurai, Iranian "Tarighat" (route to the truth), etc.

Finally a word of caution about the future: the future of ELT will depend on to what extent practice will be able to catch up with theory. Theories are being accumulated. With this bulk of literature, we need to think more seriously about the future of practice.

\section{ACKNOWLEDGMENT}

The author is grateful to Dr. Mahmoud Reza Atai for his insightful comments on the content of the present article.

\section{REFERENCES}

[1] Allwright, R. L. (1991). The death of the method (Working Papers No. 10). Lancaster, England: The University of Lancaster, The Exploratory Practice Center.

[2] Anthony, E. M. (1963). Approach, method and technique. English Language Teaching, 17, 63-67.

[3] Asher, J. J. (1969). The total physical response approach to second language learning. Modern Language Journal, 53, 3-17.

[4] Bakhtin, M. (1986). Speech genres and other late essays. Austin: University of Texas Press.

[5] Bartolomé, L. (2003). Beyond the methods fetish: Toward a humanizing pedagogy. In A. Darder, M. Baltodano, \& R. D. Torres (Eds.), The Critical Pedagogy Reader (pp. 408-439). New York: RoutledgeFalmer. 
[6] Beck, C. (1993). Postmodernism, pedagogy, and philosophy of education. Philosophy of Education. Yearbook [electronic version]. Retrieved January 26, 2008, from http://www.ed.uiuc.edu/EPS/PES-Yearbook/93-docs/

[7] Bell, D. (2003). Method and postmethod: Are they really incompatible? TESOL Quarterly, 37, 325-336.

[8] Bhatia, V. J. (1993). Analyzing genre: Language use in professional settings. London: Longman.

[9] Blum-Kulka, S., House, J., \& Kasper, G. (Eds.) (1989). Cross-cultural pragmatics: Requests and apologies. Norwood, NJ: Ablex.

[10] Bourdieu, P. (1991). Language and symbolic power. Cambridge: Polity Press.

[11] Brown, H. D. (1991). TESOL at twenty-five: What are the issues? TESOL Quarterly, 25, 245-260.

[12] Brown, H. D. (2002). English language teaching in the "postmethod" era: Toward better diagnosis, treatment, and assessment. In J. C. Richards \& W. A. Renandya (Eds.), Methodology in language teaching (pp. 9-25). Cambridge: Cambridge University Press.

[13] Brown, G., \& Yule, G. (1983). Discourse analysis. Cambridge: Cambridge University Press.

[14] Bygate, M., Skehan, P., \& Swain, M. (Eds.) (2001). Introduction. Researching pedagogic tasks: Second language learning, teaching and testing. Harlow: Longman.

[15] Clarke, M. A. (1990). Some cautionary observations on liberation education. Language Arts, 67 (4), 388-398.

[16] Clarke, M. A. (1994). The dysfunctions of the theory/practice discourse. TESOL Quarterly, 28 (1), 9-26.

[17] Clarke, M. A., \& Silberstein, S. (1988). Problems, prescriptions and paradoxesin second language teaching. TESOL Quarterly, 22 (4), 684-700.

[18] Chomsky, N. (1959). A review of B. F. Skinner's Verbal Behavior. Language, 35 (1), 26-28.

[19] Chomsky, N. (1975). Syntactic structures. The Hague: Mouton.

[20] Curran, C. A. (1972). Counseling-learning: A whole-person model for education. New York: Grune and Stratton.

[21] Curran, C. A. (1976). Counseling-learning in second languages. Apple River, Ill: Apple River Press.

[22] Darder, A., Baltodano, M., \& Torres, R. D. (Eds.), The Critical Pedagogy Reader. New York: RoutledgeFalmer.

[23] Derrida, J. (1978). Writing and difference (A. Bass, Trans.). London: Routledge \& Kegan Paul.

[24] Dewey, J. (1966). Democracy and education. New York: The Free Press.

[25] Dewey, J. (1963). Experience and education. New York: Collier Books.

[26] Doll, E. (2002). Beyond methods? Teaching as an aesthetic and spiritual quest [electronic version].In E. Mirochnik \& D. C. Sherman (Eds.), Passion and Pedagogy: Relation, creation, and Transformation in teaching. Retrieved 15.6.2007 from http://www.lsu.edu/faculty/wdoll/mypapers_new.htm

[27] Elliott, J. (1993). Reconstructing teacher education: Teacher Development. London: Falmer Press.

[28] Fairclough, N. (1989). Language and power. London: Longman.

[29] Finocchiaro, M. (1971). Myth and reality in TESOL: A plea for a broader view. TESOL Quarterly, 5, 3-17.

[30] Foucault, M. (1972). The archeology of knowledge. New York: Tavistock.

[31] Foucault, M. (1980). Power and knowledge. New York: Pantheon.

[32] Freire, P. (1972). Pedagogy of the oppressed (M. Bergman Ramos, Trans.). London: Penguin Books.

[33] Freire, P. (1998). Pedagogy of freedom: Ethics, democracy, and civic courage (P.Clarke, Trans.). Maryland: Rowman \& Littlefield.

[34] Gramsci, A. (1971). Selection from the prison notebooks. New York: International Publishers.

[35] Giroux, H. (1988). Teachers as intellectuals: Toward a critical pedagogy of learning. South Hadley, Mass.: Bergin \& Garvey.

[36] Gumperz, J. (1982). Discourse strategies. Cambridge: Cambridge University Press

[37] Halliday, M. A. K. (1985). An introduction to functional grammar. London: Edward Arnold.

[38] Hornby, A. S. (1954). Guide to patterns and usage in English. London: Oxford University Press.

[39] Hornby, A. S. (1959). The teaching of structural words and sentence patterns. London: Oxford University Press.

[40] Howatt, A. P. R. (1984). A history of language teaching. Oxford: Oxford University Press.

[41] Howatt, A. P. R. (with Widdowson H. D.) (2004). A history of language teaching. Oxford: Oxford University Press.

[42] Hutcheon, L. (1989). The politics of postmodernism. London: Routledge.

[43] Jameson, F. (1984). Foreword, In J. F. Lyotard, The postmodern condition: A report on knowledge (G. Bennington \& B. Massumi, Trans.). Minneapolis: University of Minnesota Press.

[44] Janson, H. W., \& Janson, A. (1995). History of art. London: Prentice Hall.

[45] Keeves, J. P., \& Lakomsky, G. (1999). Issues in educational research. Oxford: Elsevier Science.

[46] Kelly, L. (1969). 25 centuries of language teaching. Rowley, Mass.: Newbury House.

[47] Krashen, S., \& Terrell, T. (1983). The natural approach: Language acquisition in the classroom. Oxford: Pergamon.

[48] Kumaravadivelu, B. (1992). Macrostrategies for the second/foreign language teacher. Modern Language Journal, 76 (1), $41-49$.

[49] Kumaravadivelu, B. (1993). Maximizing learning potential in the communicative classroom. ELT Journal, 47, 12-25.

[50] Kumaravadivelu, B. (1994). The postmethod condition: (E)merging strategies for second/foreign language teaching. TESOL Quarterly, 28, 27-48.

[51] Kumaravadivelu, B. (1995). The author responds. TESOL Quarterly, 29, 177-180.

[52] Kumaravadivelu, B. (2001). Toward a postmethod pedagogy. TESOL Quarterly, 35, 537- 560.

[53] Kumaravadivelu, B. (2003). Beyond methods: Macrostrategies for language learning. New Haven, CT: Yale University Press.

[54] Kumaravadivelu, B. (2006a). Understanding language teaching: from method to postmethod. Mahwah, N. J.: Lawrence Erlbaum.

[55] Kumaravadivelu, B. (2006b). TESOL methods: Changing tracks, challenging methods. TESOL Quarterly, 40 (1), 59-77.

[56] Larson-Freeman, D. (2005a). A critical analysis of postmethod. ILI Language Teaching Journal, 1(1), 21-25.

[57] Larson-Freeman, D. (2005b). On the appropriateness of language teaching methods in language and development. ILI Language Teaching Journal, 1 (2), 1-14.

[58] Liu, D. (1995). Comments on B. Kumaravadivelu's "The postmethod condition: (E)merging strategies for second/foreign language teaching": "Alternative to" or "addition to" method? TESOL Quarterly, 29, 147-177. 
[59] Lozanov, G. (1978). Suggestology and outline of suggestopedy. New York: Gordon and Breach.

[60] Lyotard, J. F. (1984). The postmodern condition: A report on knowledge (G. Bennington \& B. Massumi, Trans.). Minneapolis: University of Minnesota Press.

[61] Mackey, W. F. (1965). Language teaching analysis. London: Longman.

[62] Marshal, J., \& Peters, M. (1999). Postmodernism. In J. P. Keeves, \& G. Lakomsky (EDs.). Issues in educational research (pp. 242-245). Oxford: Elsevier Science.

[63] Mazlow, A. (1967). Self-actualization and beyond. In J. F. T. Bugental (ED.), Challenges of Humanistic Psychology (pp. ). New York: McGraw Hill.

[64] Miege, G. (1685). Nouvelle Methode pour apprendre l'Anglois, avec une Nomenclature, Francoise Angloise; un Recueil d' Expressions familieres; et des dialogues, familiers et choisis. London: for Thomas Bassett (Scholar Press 152, 1969) [cited in Howatt, 2004].

[65] Noddings, N. (1998). Philosophy of education. Oxford: Westview Press.

[66] Oxford Dictionary of Word Histories. (2002). Oxford: Oxford University Press.

[67] Pennycook, A. (1989). The concept of method, interested knowledge, and the politics of language teaching. TESOL Quarterly, 23, 589-618.

[68] Piaget, J. (1951). Psychology of intelligence. London: Routledge and Kegan.

[69] Piaget, J. (1971). Biology and knowledge. Chicago: University of Chicago Press.

[70] Prabhu, N. S. (1990). There is no best method-why? TESOL Quarterly, 24, 161-176.

[71] Richards, J. C. (1990). Beyond methods. In J. C. Richards (Ed.), The language teaching matrix. New York: Cambridge University Press.

[72] Richards, J. C. (2001). Beyond methods. In C. N. Candlin \& N. Mercer (Eds.), English language teaching in its social context (pp. 167-179). London: Routledge.

[73] Richards, J. C., \& Rodgers, T. (1986). Approaches and methods in language teaching. Cambridge: Cambridge University Press.

[74] Richards, J. C., \& Rodgers, T. (2001). Approaches and methods in language teaching (2nd ed.).Cambridge: Cambridge University Press.

[75] Roger, C. R. (1968). Interpersonal relationship: USA 2000. Journal of Applied Behavioral Sciences, 4, 265-280.

[76] Savignon, S. (1991). Communicative language teaching: State of the art. TESOL Quarterly, 15, 261-277.

[77] Savignon, S. (2007). Beyond communicative language teaching: What's ahead? Journal of Pragmatics, 39, $207-220$.

[78] Sinclair, J., \& Coulthard, R. M. (1975). Towards an analysis of discourse: The English used by teachers and pupils. Oxford: Oxford University Press.

[79] Skinner, B. F. (1957). Verbal Behavior. New York: Appleton-Century-Crofts.

[80] Solomon, R. C., \& Higgins, K. M. (1996). A short history of philosophy. Oxford: Oxford University Press.

[81] Stern, H. H. (1983). Fundamental concepts of language teaching. Oxford: Oxford University Press.

[82] Swaffar, J. K., Arens, K., \& Morgan, M. (1982). Teacher classroom practices: Redefining method as task hierarchy. The Modern Language Journal, 66, 24-23.

[83] Swales, J. (1990). Genre analysis: English in academic and research settings. Cambridge: Cambridge University Press.

[84] Vygotsky, L. (1978). Mind in society (M. Cole, V. John-Steiner, S. Scribner, \& E. Souberman, Eds.). Cambridge, Mass.: Harvard University Press.

[85] Vygotsky, L. (1986). Thought and language. Cambridge, Mass.: MIT Press.

[86] Wodak, R. (1989). Language, power and ideology: Studies in political discourse. Amsterdam: John Benjamins.

[87] Wolfreys, J. (1998). Deconstruction. Derrida. London: McMillan.

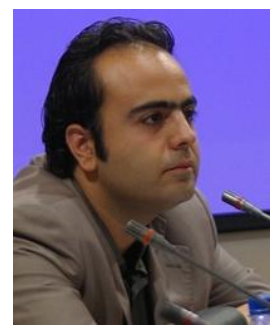

Seyyed Mohammad Reza Hashemi is Head of Research \& Planning Department at the Iran Language Institute. He has a BS in civil engineering and an MA in TEFL. He is currently perusing a PhD in TEFL at University for Teacher Education, Tehran, Iran. He has published papers on materials development and task-based language teaching. He has taught research methods in applied linguistics and language testing at University for Teacher Education and Allameh Tabatabai'i University in Tehran. His areas of interest are materials development and language testing. 